\title{
PERSEPSI KEHARMONISAN KELUARGA TERHADAP KECENDERUNGAN KENAKALAN REMAJA DI DESA TANJUNG RAMAN KECAMATAN PENDOPO KABUPATEN EMPAT LAWANG
}

\author{
Indah Pusnita \\ Dosen Stisipol Candradimuka Palembang \\ Email: pusnitaindah@gmail.com
}

\begin{abstract}
The study with the title: Perceptions of Family Harmony Against Juvenile Delinquency Tendencies in Tanjung Raman Village, Pendopo District, Empat Lawang Regency. Social problems that are categorized as deviant behavior include juvenile delinquency. To find out about the background of juvenile delinquency, it can be done through two approaches, namely an individual approach and a systems approach. In the individual approach, the individual is the unit of observation as well as the source of the problem. For the systems approach, the individual is the unit of observation while the system is the source of the problem. Based on the research conducted, it was found that there was a negative relationship between juvenile delinquency and family functioning. This means that the increasing social functioning of a family in carrying out life's tasks, roles and functions, the lower the children's level of delinquency or the lower the quality of the delinquency. In addition, the use of free time that is not directed is a very dominant cause for adolescents to perform deviant behavior.
\end{abstract}

Keywords: Perceptions of Family Harmony and Juvenile Delinquency

\begin{abstract}
ABSTRAK
Penelitian dengan judul Persepsi Keharmonisan Keluarga Terhadap Kecenderungan Kenakalan Remaja Di Desa Tanjung Raman Kecamatan Pendopo Kabupaten Empat Lawang. Masalah sosial yang dikategorikan dalam perilaku menyimpang diantaranya adalah kenakalan remaja. Untuk mengetahui tentang latar belakang kenakalan remaja dapat dilakukan melalui dua pendekatan yaitu pendekatan individual dan pendekatan sistem. Dalam pendekatan individual, individu sebagai satuan pengamatan sekaligus sumber masalah. Untuk pendekatan sistem, individu sebagai satuan pengamatan sedangkan sistem sebagai sumber masalah. Berdasarkan penelitian yang dilakukan diperoleh hasil bahwa ternyata ada hubungan negative antara kenakalan remaja dengan keberfungsian keluarga. Artinya semakin meningkatnya keberfungsian sosial sebuah keluarga dalam melaksanakan tugas kehidupan, peranan, dan fungsinya maka akan semakin rendah tingkat kenakalan anak-anaknya atau kualitas kenakalannya semakin rendah. Di samping itu penggunaan waktu luang yang tidak terarah merupakan sebab yang sangat dominan bagi remaja untuk melakukan perilaku menyimpang.
\end{abstract}

Kata Kunci: Persepsi Keharmonisah Keluarga dan Kenakalan Remaja

\section{A. PENDAhULUAN}

Masa remaja awal merupakan masa transisi, dimana usianya berkisar antara 13 sampai 16 tahun atau yang biasa disebut dengan usia belasan yang tidak menyenangkan, dimana terjadi juga perubahan pada dirinya baik secara fisik, psikis, maupun secara sosial. Pada masa transisi tersebut kemungkinan dapat menimbulkan masa krisis, yang ditandai dengan kecenderungan munculnya perilaku menyimpang. Pada kondisi tertentu perilaku menyimpang tersebut akan menjadi perilaku yang mengganggu. Melihat kondisi tersebut apabila didukung oleh lingkungan yang kurang kondusif dan sifat kepribadian yang kurang baik akan menjadi pemicu timbulnya berbagai penyimpangan perilaku dan perbuatan-perbuatan negatif yang melanggar aturan dan norma yang ada di 
E. ISSN : 2746-1629

masyarakat yang biasanya disebut dengan kenakalan remaja.

Kenakalan remaja dalam studi sosial dapat dikategorikan ke dalam perilaku menyimpang. Dalam perspektif perilaku menyimpang masalah sosial terjadi karena terdapat penyimpangan perilaku dari berbagai aturanaturan sosial ataupun dari nilai dan norma sosial yang berlaku. Perilaku menyimpang dapat dianggap sebagai sumber masalah karena dapat membahayakan tugaknya sistem sosial. Penggunaan konsep perilaku menyimpang secara tersirat mengandung makna bahwa ada jalur baku yang harus ditempuh. Perilaku yang tidak melalui jalur tersebut berarti telah menyimpang.

Untuk mengetahui latar belakang perilaku menyimpang perlu membedakan adanya perilaku menyimpang yang tidak disengaja dan yang disengaja, diantaranya karena pelaku kurang memahami aturan-aturan yang ada, perilaku menyimpang yang disengaja, bukan karena pelaku tidak mengetahui aturan. Hal yang relevan untuk memahami bentuk perilaku tersebut, adalah mengapa seseorang melakukan penyimpangan, padahal ia tahu apa yang dilakukan melanggar aturan. Becker (dalam Soerjono Soekamto, 1998) mengatakan bahwa tdak ada alasan untuk mengassumsikan hanya mereka yang menyimpang mempunyai dorongan untuk berbuat demikian. Hal ini disebabkan karena pada dasarnya setiap manusia pasti mengalami dorongan untuk melanggar pada situasi tertentu, tetapi mengapa pada kebanyakan orang tidak menjadi kenyataan yang berwujud penyimpangan, sebab orang dianggap normal biasanya dapat menahan diri dari dorongandorongan untuk menyimpang.

Untuk mengetahui latar belakang perilaku menyimpang perlu membedakan adanya perilaku menyimpang yang tidak disengaja dan yang disengaja, diantaranya karena si pelaku kurang memahami aturan-aturan yang ada. Sedangkan perilaku yang menyimpang yang disengaja, bukan karena si pelaku tidak mengetahui aturan. Hal yang relevan untuk memahami bentuk perilaku tersebut, adalah mengapa seseorang melakukan penyimpangan, sedangkan ia tahu apa yang dilakukan melanggar aturan. Becker (dalam Soerjono Soekanto,1998,26), mengatakan bahwa tidak ada alasan untuk mengasumsikan hanya mereka yang menyimpang mempunyai dorongan untuk berbuat demikian. Hal ini disebabkan karena pada dasarnya setiap manusia pasti mengalami dorongan untuk melanggar pada situasi tertentu, tetapi mengapa pada kebanyakan orang tidak menjadi kenyataan yang berwujud penyimpangan, sebab orang dianggap normal biasanya dapat menahan diri dari dorongandorongan untuk menyimpang.

Kenakalan-kenakalan yang dilakukan oleh remaja di bawah usia 17 tahun sangat beragam mulai dari perbuatan yang amoral dan anti sosial tidak dapat dikategorikan sebagai pelanggaran hukum. Bentuk kenakalan remaja tersebut seperti: kabur dari rumah, membawa senjata tajam, dan kebut-kebutan di jalan, sampai pada perbuatan yang sudah menjurus pada perbuatan kriminal atau perbuatan yang melanggar hukum seperti: pembunuhan, perampokan, pemerkosaan, seks bebas, pemakaian obat-obatan terlarang, dan tindak kekerasan lainnya yang sering diberitakan media-media masa.

Berdasarkan hasil beberapa penelitian ditemukan bahwa salah satu faktor penyebab timbulnya kenakalan remaja adalah tidak berfungsinya orang tua sebagai figur tauladan bagi anak (Hawari, 2000). Selain itu suasana keluarga yang menimbulkan rasa tidak aman dan tidak menyenangkan serta hubungan keluarga yang kurang baik dapat menimbulkan bahaya psikologis bagi setiap usia terutama pada masa remaja. Menurut Hirschi (dalam Mussen dkk, 2000) orang tua dari remaja nakal cenderung memiliki aspirasi yang minim mengenai anak-anaknya, menghindari keterlibatan keluarga dan kurangnya bimbingan orangtua terhadap remaja. Sebaliknya, suasana keluarga yang menimbulkan rasa aman dan menyenagkan akan menumbuhkan kepribadian yang wajar dan begitu pula sebaliknya.

Banyak penelitian yang dilakukan para ahli menemukan bahwa remaja yang berasal dari keluarga yang penuh perhatian, hangat, dan harmonis mempunyai kemampuan dalam menyesuaikan diri dan sosialisai yang baik dengan lingkungan sekitarnya. Selanjutnya Tallent menambahkan anak yang mempunyai penyesuaian diri yang baik di sekolah, 
biasanya memiliki latar belakang keluarga yang harmonis, menghargai pendapat anak dan hangat. Hal ini disebabkan karena anak yang berasal dari keluarga yang harmonis akan mempersepsi rumah mereka sebagai suatu tempat yang membahagiakan karena semakin sedikit masalah antara orangtua, maka semakin sedikit masalah yang dihadapi anak, dan begitu juga sebaliknya jika anak mempersepsi keluarganya berantakan atau kurang harmonis maka ia akan terbebani dengan masalah yang sedang dihadapi oleh orangtuanya tersebut.

Faktor lain yang juga ikut mempengaruhi perilaku pada remaja adalah konsep diri yang merupakan pandangan atau keyakinan diri terhadap keseluruhan diri, baik yang menyangkut kelebihan maupun kekurangan diri, sehingga mempunyai pengaruh yang besar terhadap keseluruhan perilaku yang ditampilkan.

Conger menyatakan bahwa remaja nakal biasanya mempunyai sifat memberontak, ambivalen terhadap otoritas, mendendam, curiga, implusif dan menunjukkan kontrol batin yang kurang. Sifat -sifat tersebut mendukung perkembangan konsep diri yang negatif. Dengan demikian remaja yang dibesarkan dalam keluarga yang kurang harmonis dan memiliki konsep diri negatif kemungkinan memiliki kecenderungan yang lebih besar menjadi nakal dibandingkan remaja yang dibesarkan dalam keluarga dan memiliki konsep diri positif.

\section{B. LANDASAN TEORI}

\section{Keharmonisan Keluarga}

Keluarga merupakan satu orgaisasi sosial yang paling penting dalam kelompok sosial dan keluarga merupakan lembaga di dalam masyarakat yang paling utama bertanggung jawab untuk menjamin kesejahteraan sosial dan kelestarian biologis anak manusia. Sedangkan menurut Hawari (2000) keharmonisan keluarga itu akan terwujud apabila masing-masing unsur dalam keluarga itu dapat berfungsi dan berperan sebagaimana mestinya dan tetap berpegang teguh pada nilainilai agama kita, maka interaksi sosial yang harmonis antar unsur dalam keluarga itu akan dapat diciptakan.

Dalam kehidupan berkeluarga antara suami istri dituntut adanya hubungan yang baik dalam arti diperlukan suasana yang harmonis yaitu dengan menciptakan saling pengertian, saling terbuka, saling menjaga, saling menghargai dan saling memenuhi kebutuhan.

Setiap orang tua bertanggung jawab juga memikirkan dan mengusahakan agar senantiasa terciptakan dan terpelihara suatu hubungan antara orangtua dengan anak yang baik, efektif dan menambah kebaikan dan keharmonisan hidup dalam keluarga, sebab telah menjadi bahan kesadaran para orangtua bahwa hanya dengan hubungan yang baik kegiatan pendidikan dapat dilaksanakan dengan efektif dan dapat menunjang terciptanya kehidupan keluarga yang harmonis.

Keharmonisan keluarga didalamnya tercipta kehidupan beragama yang kuat, suasana yang hangat, saling menghargai, saling pengertian, saling terbuka, saling menjaga dan diwarnai kasih sayang dan rasa saling percaya sehingga memungkinkan anak untuk tumbuh dan berkembang secara seimbang.

Hawari dalam Murni mengemukakan enam aspek sebagai suatu pegangan hubungan perkawinan bahagia adalah :

a. Menciptakan kehidupan beragama dalam keluarga

Sebuah keluarga yang harmonis ditandai dengan terciptanya kehidupan beragama dalam rumah tersebut. Hal ini penting karena dalam agama terdapat nilai-nilai moral dan etika kehidupan. Berdasarkan beberapa penelitian ditemukan bahwa keluarga yang tidak religius yang penanaman komitmennya rendah atau tanpa nilai agama sama sekali cenderung terjadi pertentangan konflik dan percekcokan dalam keluarga, dengan suasana yang seperti ini, maka anak akan merasa tidak betah di rumah dan kemungkinan besar anak akan merasa tidak betah di rumah dan kemungkinan besar anak akan mencari lingkungan lain yang dapat menerimanya.

b. Mempunyai waktu bersama keluarga 


\section{E. ISSN : 2746-1629}

Keluarga yang harmonis selalu menyediakan waktu untuk bersama keluarganya, baik itu hanya sekedar berkumpul, makan bersama, menemani anak bermain dan mendengarkan masalah dan keluhan-keluhan anak, dalam kebersamaan ini anak akan merasa dirinya dibutuhkan dan diperhatikan oleh orangtuanya, sehingga anak akan betah tinggal di rumah.

c. Mempunyai komunikasi yang baik antar anggota keluarga

Komunikasi merupakan dasar bagi terciptanya keharmonisan dalam keluarga. Remaja akan merasa aman apabila orangtuanya tampak rukun, karena kerukunan tersebut akan memberikan rasa aman dan ketenangan bagi anak, komunikasi yang baik dalam keluarga juga akan dapat membantu remaja untuk memecahkan permasalahan yang dihadapinya di luar rumah, dalam hal ini selain berperan sebagai orangtua, ibu dan ayah juga harus berperan sebagai teman, agar anak lebih leluasa dan terbuka dalam menyampaikan semua permasalahannya.

d. Saling menghargai antar sesama anggota keluarga

Keluarga yang harmonis adalah keluarga yang memberikan tempat bagi setiap anggota keluarga menghargai perubahan yang terjadi dan mengajarkan keterampilan berinteraksi sedini mungkin pada anak dengan lingkungan yang lebih luas.

e. Kualitas dan kuantitas konflik yang minim

Faktor lain yang tidak kalah penting dalam menciptakan keharmonisan keluarga adalah kualitas dan kuantitas konflik yang minim, jika dalam keluarga sering terjadi perselisihan dan pertengkaran maka suasana dalam keluarga tidak lagi menyenangkan. Dalam keluarga harmonis setiap anggota keluarga berusaha menyelesaikan masalah dengan kepala dingin dan mencari penyelesaian terbaik dari setiap permasalahan.

f. Adanya hubungan atau ikatan yang erat antar anggota keluarga

Hubungan yang erat antar anggota juga menentukan harmonisnya sebuah keluarga, apabila dalam suatu keluarga tidak memiliki hubungan yang erat maka antar anggota keluarga tidak ada lagi rasa saling memiliki dan rasa kebersamaan akan kurang. Hubungan yang erat antar anggota keluarga ini dapat diwujudkan dengan adanya kebersamaan, komunikasi yang baik antar anggota keluarga dan saling mengahargai.

\section{Faktor-Faktor Yang Mempengaruhi} Keharmonisan Keluarga :

a. Komunikasi interpersonal

Komunikasi interpersonal merupakan faktor yang sangat mempengaruhi keharmonisan keluarga, karena menurut Hurlock komunikasi akan menjadikan seseorang mampu mengemukakan pendapat dan pandangannya, sehingga mudah untuk memahami orang lain dan sebaliknya tanpa adanya komunikasi kemungkinan besar dapat menyebabkan terjadinya kesalahpahaman yang memicu terjadinya konflik.

b. Tingkat ekonomi keluarga

Menurut beberapa penelitian, tingkat ekonomi keluarga juga merupakan salah satu faktor yang menentukan keharmonisan keluarga. Jogersen (dalam Murni 2004) menemukan dalam penelitiannya bahwa semakin tinggi sumber ekonomi keluarga akan mendukung tingginya stabilitas dan kebahagiaan keluarga, tetapi tidak berarti rendahnya tingkat ekonomi keluarga merupakan indikasi tidak bahagianya keluarga. Tingkat ekonomi hanya berpengaruh terhadap kebahagian keluarga apabila berada pada taraf yang sangat rendah sehingga kebutuhan dasar saja tidak terpenuhi dan inilah nantinya yang akan menimbulkan konflik dalam keluarga.

c. Sikap orangtua

Sikap orang tua juga berpengaruh terhadap keharmonisan keluarga terutama hubungan dengan anak-anaknya. Orangtua dengan sikap yang otoriter akan membuat suasana dalam keluarga menjadi tegang dan anak merasa tertekan, anak tidak diberi kebebasan untuk mengeluarkan pendapatnya, semua keputusan ada ditangan orangtuanya sehingga membuat remaja itu merasa tidak mempunyai peran dan merasa kurang dihargai dan kurang kasih sayang serta memandang orangtuanya tidak bijaksana. Orangtua yang permisif cenderung mendidik anak terlalu bebas dan tidak terkontrol karena apa yang dilakukan anak tidak pernah mendapat bimbingan dari orangtua. Kedua sikap tersebut cenderung memberikan peluang yang besar untuk menjadikan anak berperilaku menyimpang, 
sedangkan orangtua yang bersikap demokratis dapat menjadi pendorong perkembangan anak kearah yang lebig positif.

\section{d. Ukuran keluarga}

Menurut Kodwel (1981) dengan jumlah anak dalam satu keluarga cara orangtua mengontrol perilaku anak, menetapkan aturan, mengasuh dan perlakuan efektif orangtua terhadap anak. Keluarga yang lebih kecil mempunyai kemungkinan lebih besar untuk memperlakukan anaknya secara demokratis dan lebih baik untuk kelekatan anak dengan orangtua.

\section{Definisi Remaja}

WHO dalam Sarwono (2003), mendifinisikan remaja lebih bersifat konseptual, ada tiga kriteria yaitu biologis, psikologik, dan sosial ekonomi, dengan batasan usia antara 10-20 tahun, yang secara lengkap definisi tersebut berbunyi sebagai berikut:

a. Individu berkembang dari saat pertama kali ia menunjukkan tanda-tanda seksual sekundernya sampai saat ia mencapai kematangan seksual.

b. Individu mengalami perkembangan psikologik dan pola identifikasi dari kanakkanak menjadi dewasa.

c. Terjadi peralihan dari ketergantungan sosial-ekonomi yang penuh kepada keadaan yang relatif lebih mandiri.

Senada Suryabrata membagi masa remaja menjadi tiga, masa remaja awal 12-15 tahun, masa remaja pertengahan 15-18 tahun dan masa remaja akhir 18-21 tahun.

Masa remaja merupakan awal salah satu periode perkembangan yang dialami oleh setiap individu, sebagai masa transisi dari masa kanak-kanak menuju masa dewasa. Pada masa remaja ini ada beberapa perubahan yang bersifat universal, yaitu :

1. Meningkatnya emosi

2. perubahan fisik

3. perubahan terhadap minat dan peran

4. perubahan pola perilaku

5. nilai-nilai dan sikap ambivalen terhadap setiap perubahan.
Berikut ini dijelaskan satu persatu dari ciriciri perubahan yang terjadi pada masa remaja : a. Perubahan fisik

Perubahan fisik berhubungan dengan aspek ekonomi dan aspek fisiologis, di masa remaja kelenjar hipofesa menjadi masak dan mengeluarkan beberapa hormone, seperti hormone gonotrop yang berfungsi untuk mempercepat kemasakan sel telur dan sperma, serta mempengaruhi produksi hormon kortikortop berfungsi mempengaruhi kelenjar suprenalis, testoterone, oestrogen, dan suprenalis yang mempengaruhi pertumbuhan anak sehingga terjadi percepatan pertumbuhan. Dampak dari produksi hormone tersebut adalah :

1. ukuran otot betambah dan semakin kuat

2. testosteron menghasilkan sperma dan oestrogen memproduksi sel telur sebagai tanda kemasakan.

3. munculnya tanda-tanda kelamin sekunder seperti membesarnya payudara, berubahnya suara, ejakulasi pertama, tumbuhnya rambut-rambut halus disekitar kemaluan, ketiak dan muka.

b. Perubahan emosional

Pola emosi pada masa remaja dengan pola emosi pada masa kanak-kanak. Pola-pola emosi itu berupa marah, cemburu, ingin tahu, iri hati, gembira, sedih dan kasih sayang. Perbedaan terletak pada rangsangan yang membangkitkan emosi dan pengendalian dalam mengekspresikan emosi. Remaja umumnya memiliki kondisi emosi yang labil pengalaman emosi yang ekstrem dan selalu merasa mendapatkan tekanan. Bila pada akhir masa remaja mampu menahan diri untuk tidak mengekspresikan emosi secara ekstrem dan mampu mengekpresikan emosi secara tepat sesuai dengan situasi dan kondisi lingkungan dan dengan cara yang dapat diterima masyarakat, dengan kata lain remaja yang mencapai kematangan emosi akan memberikan reaksi emosi yang stabil. Ciri-ciri kematangan emosi pada masa remaja yang ditandai dengan sikap sebagai berikut:

1. Tidak bersikap kekanak-kanakan

2. bersikap nasional 
E. ISSN : 2746-1629

3. bersikap objektif

4. dapat menerima kritikan orang lain sebagai pedoman untuk bertindak lebih lanjut

5. bertanggung jawab terhadap tindakan yang dilakukan

6. mampu menghadapi masalah dan tantangan yang dihadapi

c. Perubahan sosial

Perubahan fisik dan emosi pada masa remaja juga mengakibatkan perubahan dan perkembangan remaja yaitu, memisahkan diri dari orangtua dan menuju kearah teman sebaya. Remaja berusaha melepaskan diri dari otoritas orangtua dengan maksud menemukan jati diri. Remaja lebih banyak berada di luar rumah dan berkumpul bersama teman sebayanya dengan membentuk kelompok dan mengekspresikan segala potensi yang dimiliki. Kondisi ini membuat remaja sangat rentan terhadap pengaruh teman dalam hal minat, sikap penampilan dan perilaku. Perubahan yang paling menonjol adalah hubungan heteroseksual. Remaja akan memperlihatkan perubahan radikal dari tidak menyukai lawan jenis menjadi lebih menyukai. Remaja ingin diterima, diperhatikan dan dicintai oleh lawan jenis dan kelompoknya.

\section{Kenakalan Remaja}

Kenakalan remaja biasa disebut dengan istilah Juvenile berasal dari bahasa Latin juvenilis, yang artinya anak-anak, anak muda, ciri karakteristik pada masa muda, sifat-sifat khas pada periode remaja, sedangkang delinquent berasal dari bahasa latin "delinquere" yang berarti terabaikan, mengabaikan, yang kemudian diperluas artinya menjadi jahat, nakal, anti sosial, kriminal, pelanggar aturan, pembuat ribut, pengacau peneror, durjana dan lain sebagainya.

"Juvenile delinquncy atau kenakalan remaja adalah perilaku jahat atau kenakalan anak-anak muda, merupakan gejala sakit (patologi) secara sosial pada anak-anak dan remaja yang disebabkan oleh satu bentuk pengabaian sosial, sehingga mereka mengembangkan bentuk perilaku yang menyimpang. Istilah kenakalan remaja mengacu pada suatu rentang yang luas, dari tingkah laku yang tidak dapat diterima sosial sampai pelanggaran status hingga tindak kriminal."

Mussen dkk, mendifiniskan kenakalan remaja sebagai perilaku yang melanggar hukum atau kejahatan yang biasanya dilakukan oleh anak remaja yang berusia 16-18 tahun, jika perbuatan ini dilakukan oleh orang dewasa maka akan mendapat sangsi hukum.

Kenakalan remaja adalah tindakan pelanggaran hukum yang dilakukan remaja, dimana tindakan tersebut dapat membuat seseorang individu yang melakukannya masuk penjara.

Sarwono mengungkapkan kenakalan remaja sebagai tingkah laku yang menyimpang dari norma-norma hukum pidana, sedangkan Fuhrmann menyebutkan bahwa kenakalan remaja suatu tindakan anak muda yang dapat merusak dan mengganggu, baik terhadap diri sendiri maupun orang lain.

Dari pendapat-pendapat di atas dapat disimpulkan bahwa kecenderungan kenakalan remaja adalah kecenderungan kenakalan remaja adalah kecenderungan remaja untuk melakukan tindakan yang melanggar aturan yang dapat mengakibatkan kerugian dan kerusakan baik terhadap dirinya maupun orang lain yang dilakukan remaja di bawah umur 17 tahun.

\subsubsection{Bentuk dan Aspek-Aspek Kenakalan Remaja}

Menurut Kartono, bentuk-bentuk perilaku kenakalan remaja dibagi menjadi empat yaitu :
a. Kenakalan
terisolir
(Delinkuensi terisolir)is.

Kelompok ini merupakan jumlah terbesar dari remaja nakal. Pada umumnya mereka tidak menderita kerusakan psikolog Perbuatan nakal mereka didorong oleh faktor-faktor berikut:

1) Keinginan meniru dan ingin konform dengan gangnya, jadi tidak ada motivasi, kecemasan atau konflik batin yang tidak dapat diselesaikan.

2) Mereka kebanyakan berasal dari daerah kota yang transisional sifatnya yang memiliki subkultur kriminal. Sejak kecil remaja melihat adanya gang-gang kriminal, sampai kemudian dia ikut bergabung. Remaja merasa diterima, mendapatkan 
kedudukan hebat, pengakuan dan presstise tertentu.

3) Pada umumnya remaja berasal dari keluarga berantakan, tidak harmonis, dan mengalami banyak frustasi. Sebagai jalan keluarnya, remaja memuaskan semua kebutuhan dasarnya di tengah lingkungan kriminal. Gang remaja nakal memberikan alternatif hidup yang menyenagkan.

4) Remaja dibesarkan dalam keluarga tanpa atau sedikit sekali mendapatkan supervisi dan latihan kedisiplinan yang teratur, sebagai akibatnya dia tidak sanggup menginternalisasikan norma hidup normal. Ringkasnya, delinkuensi terisolasi itu mereaksi terhadap tekanan dari lingkungan sosial, mereka mencari panutan dan rasa aman dari kelompok gangnya, namun pada usia dewasa, mayoritas remaja nakal ini meninggalkan prilaku kriminalnya. Paling sedikit $60 \%$ dari mereka menghentikan perilakunya pada usia 21-23 tahun. Hal ini disebabkan oleh proses pendewasaan dirinya sehingga remaja menyadari adanya tanggung jawab sebagai orang dewasa yang mulai memasuki peran sosial baru.

b. Kenakalan neurotik (Delinkuensi neurotik) Pada umumnya, reamaj nakal tipe ini menderita gangguan kejiwaan yang cukup serius, antara lain berupa kecemasan, merasa selalu tidak aman, merasa bersalah dan berdosa dan lain sebagainya. Ciri-ciri perilakunya adalah :

1) perilaku nakalnya bersumber dari sebabsebab psikologis yang sangat dalam, dan bukan hanya berupa adaptasi pasif menerima norma dan nilai sebkultur gang yang kriminal itu saja.

2) Perilaku kriminal mereka merupakan ekspresi dari konflik batin yang belum terselesaikan, karena perilaku jahat mereka merupakan alat pelepas ketakutan, kecemasan dan kebingungan batinnya.

3) Biasanya remaja ini melakukan kejahatan seorang diri, dan mempraktekkan jenis kejahatan tertentu, misalnya suka memperkosa kemudian membunuh korbannya, kriminal dan sekaligus neurotik.
4) Remaja nakal ini banyak yang berasal dari kalangan menengah, namun pada umumnya keluarga mereka mengalami banyak ketegangan emosional yang parah, dan orangtuanya bisanaya juga neurotik atau psikopatik.

5) Remaja memiliki ego yang lemah, dan cenderung mengisolir diri dari lingkungan.

6) Motif kejahatannya berbeda-beda.

7) Perilaku menunjukkan kualitas kompulsif (paksaan)

c. Kenakalan psikotik (Delinkuensi psikopatik)

Delinkuensi psikopatik ini sedikit jumlahnya, akan tetapi dilihat dari kepentingan umum dan segi keamanan, mereka merupakan oknum kriminal yang paling berbahaya. Ciri tingkah laku mereka adalah:

1) Hampir seluruh remaja delinkuensi psikopatik ini berasal dan dibesarkan dalam lingkungan keluarga yang ekstrim, brutal, diliputi banyak pertikaian keluarga, berdisiplin keras namun tidak konsisten, dan orangtuanya selalu menyia-nyiakan mereka, sehingga mereka tidak mempunyai kapasitas untuk menumbuhkan efeksi dan tidak mampu memjalin hubungan emosional yang akrab dan baik dengan orang lain.

2) Mereka tidak mampu menyadari arti bersalah, berdosa, atau melakukan pelanggaran.

3) Bentuk kejahatan majemuk, tergantung pada suasana hatinya yang kacau dan tidak dapat diduga. Mereka pada umumnya sangat agresif dan implusif dan sulit sekali diperbaiki.

4) Mereka selalu gagal dalam menyadari dan menginternalisasikan norma-norma sosial yang umum berlaku, juga tidak peduli terhadap norma subkultur gangnya sendiri.

5) Kebayakan dari mereka juga menderita gangguan neurologis, sehingga mengurangi kemampuan untuk mengendalikan diri sedniri. Psikopat merupakan bentuk kekalutan mental dengan karakteristik sebagai berikut: tidak memiliki pengorganisasian dan integrasi 
diri, orangnya tidak pernah bertanggung jawab secara moral, selalu mempunyai konflik dengan norma sosial dan hukum. Mereka sangat egois, anti sosial dan selalu menentang apa dan siapapun. Sikapnya kasar, kurang ajar dan sais terhadap siapapun tanpa sebab.

d. Kenakalan defek moral (Delinkuensi defek moral)

Defek (defect, defectus) artinya rusak, tidak lengkap, salah, cedera, cacat, kurang. Delinkuensi defek moral mempunyai ciri-ciri selalu melakukan tindakan anti sosial, walaupun pada dirinya tidak terdapat penyimpangan, namun ada disfungsi pada intelegensinya. Kelemahan para remaja delinkuen tipe ini adalah mereka tidak mampu mengenal dan memahami tingkah lakunya yang jahat, juga tidak mampu mengendalikan dan mengaturnya, mereka selalu ingin melakukan perbuatan kekerasan, penyerangan dan kejahatan, rasa kemanusiaannya sangat terganggu, sikapnya sangat dingin tanpa efeksi jadi ada kemiskinan efektif dan sterilitas emosional. Terdapat kelemahan pada dorongan instinktif yang primer, sehingga pembentukan super egonya sangat lemah. Impulsnya tetap pada taraf primitif sehingga sukar dikontrol dan dikendalikan. Mereka merasa cepat puas dengan prestasinya, namun perbuatan mereka sering disertai agresivitas yang meledak. Remaja yang efek moralnya biasanya menjadi penjahat yang sukar diperbaiki. Mereka adalah para residivis yang melakukan kejahatan karena didorong naluri rendah, impuls dan kebiasaan primitif, di antara para penjahat residivis remaja, kurang lebih $80 \%$ mengalami kerusakan psikis, berupa disposisi dan perkembangan mental yang salah, jadi mereka menderita defek mental. Hanya kurang dari $20 \%$ yang menjadi penjahat disebabkan oleh faktor sosial atau lingkungan sekitar.

Hawari membagi kenakalan remaja menjadi empat bentuk yaitu :

a. kenakalan yang menimbulkan korban fisik pada orang lain : perkelahian, perkosaan, perampokan, pembuhan, dan lain-lain.

b. Kenakalan yang menimbulkan korban materi: perusakan, pencurian, pencopetan, pemerasan dan lain-lain.

c. Kenakalan sosial yang tidak menimbulkan korban di pihak orang lain: pelacuran, penyallahgunaan obat, hubungan seks bebbas.

d. Kenakalan yang melawan status, misalnya mengingkari status anak sebagai pelajar dengan cara membolos, minggat dari rumah, membantah perintah.

Dari beberapa bentuk kenakalan pada remaja dapat disimpulkan bahwa semuanya menimbulkan dampak negatif yang tidak baik bagi dirinya sendiri dan orang lain, serta lingkungannya. Adapun aspek-aspek diambil dari pendapat Jansen, terdiri dari aspek perilaku yang melanggar aturan dan status, perilaku yang membahayakan diri sendiri dan orang lain, perilaku yang mengakibatkan korban materi, dan perilaku yang mengakibatkan korban fisik.

Menurut Kartono, remaja nakal itu mempunyai karakteristis umum yang sangat berbeda dengan remaja nakal. Perbedaan itu mencakup :

a. Perbedaan struktur intelektual

Pada umumnya intelegensi mereka tidak berbeda dengan intelegensi remaja yang normal, namun jelas terdapat fungsi-fungsi kognitif khusus yang berbeda biasanya remaja nakal ini mendapatkan nilai lebih tinggi untuk tugas-tugas prestasi daripada nilai untuk keterampilan verbal. Mereka kurang toleran terhadap hal-hal yang ambigius biasanya mereka kurang mampu memperhitungkan tingkah laku orang lain bahkan tidak menghargai pribadi lain dan menganggap orang lain sebagai cerminan dari diri sendiri.

b. Perbedaan fisik dan spikis

Remaja yang nakal ini lebih "idiot secara moral" dan memiliki perbedaan ciri karakteristik yang jasmaniah sejak lahir jika dibandingkan dengan remaja normal. Bentuk tubuh mereka lebih kekar, berotot, kuat, dan pada umumnya bersikap lebih agresif.

c. Ciri karakteristik individual

Remaja yang nakal ini mempunyai sifat kepribadian khusus yang menyimpang, seperti:

1) Rata-rata remaja nakal ini hanya berorientasi pada masa sekarang, bersenag-senag dan puas pada hari ini tanpa memikirkan masa depan.

2) Kebanyakan dari mereka terganggu secara emosional

3) Mereka kurang bersosialisasi dengan masyarakat normal, sehingga tidak 
mampu mengenal norma-norma kesusilaan, dan tidak bertanggung jawab secara sosial.

4) Mereka senang menceburkan diri dalam kegiatan tanpa berpikir yang merangsang rasa kejantanan, walaupun mereka menyadari resiko dan bahaya yang terkandung di dalalmnya.

5) Pada umumnya mereka sangat implusif dan suka tantangan dan bahaya.

6) Hati nurani tidak atau kurang lancar fungsinya

7) Kurang memiliki disiplin diri dan kontrol diri sehingga mereka menjadi liar dan jahat.

Dari uraian di atas dapat disimpulkan bahwa remaja nakal biasnya berbeda dengan remaja yang tidak nakal. Remaja nakal biasanya lebih ambivalen terhadap otoritas, percaya diri, pemberontak, mempunyai kontrol diri yang kurang, tidak mempunyai orientasi pada masa depan dan kurangnya kemasakan sosial, sehingga sulit bagi mereka untuk menyesuaikan diri dengan lingkungan sosial.

Faktor-faktor kenakalan remaja menurut Santrock lebih rinci dijelaskan sebagai berikut: a. Identitas

Menurut teori perkembangan yang dikemukakan oleh Erikson masa remaja ada pada tahap di mana krisis identitas versus difusi identitas harus diatasi. Perubahan biologis dan sosial memungkinkan terjadinya dua bentuk integrasi terjadi pada kepribadian remaja;

1) terbentuknya perasaan akan konsistensi dalam kehidupannya dan

2) tercapainya identitas peran, kurang lebih dengan cara menggabungkan motivasi, nilai-nilai, kemampuan dan gaya yang dimiliki remaja dengan peran yang dituntut dari remaja.

Erikson percaya bahwa delikuensi pada remaja terutama ditandai dengan kegagalan remaja untuk mencapai integrasi yang kedua, yang melibatkan aspek-aspek peran identitas. Ia mengatakan bahwa remaja memiliki masa balita, masa kanak-kanak atau masa remaja yang membatasi mereka dari berbagai peranan sosial yang dapat diterima atau yang membuat mereka merasa tidak mampu memenuhi tuntutan yang dibebankan pada mereka, mungkin akan memiliki perkembangan identitas yang negatif. Beberapa dari remaja ini mungkin akan mengambil bagian dalam tindakan, oleh karena itu bagi Erikson, kenakalan remaja adalah suatu upaya untuk membentuk suatu identitas, walaupun identitas tersebut negatif.

b. Kontrol diri

Kenakalan remaja juga dapat digambarkan sebagai kegagalan untuk mengembangkan kontrol diri yang cukup dalam hal tingkah laku. Beberapa anak gagal dalam mengembangkan kontrol diri yang esensial yang sudah dimiliki orang lain selama proses pertumbuhan. Kebanyakan remaja telah mempelajari perbedaan antara tingkah laku yang dapat diterima dan tingkah laku yang tidak dapat diterima, namun remaja yang melakukan kenakalan tidak mengenali hal ini. Mereka mungkin gagal membedakan tingkah laku yang dapat diterima dan yang tidak dapat diterima, atau mungkin mereka sebenarnya sudah mengetahui perbedaan antara keduanya namun gagal mengembangkan kontrol yang memadai dalam menggunakan perbedaan itu untuk membimbing tingkah laku mereka.

Remaja adalah masa peralihan dari kanakkanak ke dewasa. Para ahli pendidikan sependapat bahwa remaja adalah mereka yang berusia antara 13 sampai 18 tahun. Seorang remaja sudah tidak lagi dapat dikatakan sebagai kanak-kanak, namun masih belum cukup matang untuk dapat dikatakan dewasa. Pada tahap ini mereka sedang mencari pola hidup yang paling sesuai baginya dan inipun sering dilakukan melalui metoda coba-coba walaupun melalui banyak kesalahan. Kesalahan yang dilakukan sering menimbulkan kekuatiran serta perasaan yang tidak menyenangkan bagi lingkungan dan orang tuanya. Kesalahan yang diperbuat oleh remaja hanya akan menyenangkan teman sebayanya. Hal ini karena mereka semua memang sama-sama masih dalam masa mencari identitas dan jati diri.

Dalam proses pencarian jati dirinya seperti dijelaskan di atas, remaja sering melakukan 


\section{E. ISSN : 2746-1629}

kesalahan. Kesalahan-kesalahan yang menimbulkan kekesalan lingkungan dan keluarga inilah yang sering disebut sebagai kenakalan remaja. Pada dasarnya kenakalan remaja menunjuk pada suatu bentuk perilaku remaja yang tidak sesuai dengan norma-norma yang hidup di dalam masyarakatnya. Kartini Kartono (1988 : 93) mengatakan remaja yang nakal itu disebut pula sebagai anak cacat sosial. Mereka menderita cacat mental disebabkan oleh pengaruh sosial yang ada ditengah masyarakat, sehingga perilaku mereka dinilai oleh masyarakat sebagai suatu kelainan dan disebut "kenakalan".

Singgih D. Gumarso (2008) mengatakan dari segi hukum kenakalan remaja digolongkan dalam dua kelompok yang berkaitan dengan norma-norma hukum yaitu :

(1) kenakalan yang bersifat amoral dan sosial serta tidak diantar dalam undang-undang sehingga tidak dapat atau sulit digolongkan sebagai pelanggaran hukum ;

(2) kenakalan yang bersifat melanggar hukum dengan penyelesaian sesuai dengan undang-undang dan hukum yang berlaku sama dengan perbuatan melanggar hukum bila dilakukan orang dewasa.

Tentang normal tidaknya perilaku kenakalan atau perilaku menyimpang, pernah dijelaskan dalam pemikiran Emile Durkheim (dalam Soerjono Soekanto, 1998 : 73), bahwa perilaku menyimpang atau jahat kalau dalam batas-batas tertentu dianggap sebagai fakta sosial yang normal dalam bukunya "Rules of Sociological Method" dalam batas-batas tertentu kenakalan adalah normal karena tidak mungkin menghapusnya secara tuntas, dengan demikian perilaku dikatakan normal sejauh perilaku tersebut tidak menimbulkan keresahan dalam masyarakat, perilaku tersebut terjadi dalam batas-batas tertentu dan melihat pada sesuatu perbuatan yang tidak disengaja. Jadi kebalikan dari perilaku yang dianggap normal yaitu perilaku nakal/jahat yaitu perilaku yang disengaja meninggalkan keresahan pada masyarakat.

\section{Konsep Tentang Keluarga}

Keluarga merupakan tempat sosialisasi manusia yang pertama kali terjadi sejak dia dilahirkan ke bumi ini hingga perkembangannya menjadi dewasa. Keluarga dapat dibagi menjadi bermacam-macam, seperti keluarga inti, keluarga besar dan lainlain. Tetapi dalam bayangan kita lebih sering kita mendeskripsikan keluarga dengan gambaran keluarga inti yang terdiri dari ayah, ibu, dan saudara kandung.

Secara ideal, keluarga adalah ayah dan ibu yang bersatu dan bahu membahu dalam mendidik dan membimbing anaknya dalam masa pertumbuhan dan perkembangan. Ayah dan ibu adalah panutan anak sejak kecil hingga remaja dan hal tersebut akan berlangsung secara terus menerus. Peran keluarga sangat penting bagi sosialisasi anak di masa perkembangannya. Berikut adalah peran keluarga. Keluarga adalah kelompok terkecil dimana anggotanya berinteraksi secara tetap. Terdapat hubungan emosional yang kuat antara orang tua dan anak hubungan sosial yang terjadi relatif tetap.

Drs. Poerwita Atmaja, mengemukakan arti keluarga yaitu :

Keluarga adalah kesatuan sosial yang terdiri dari ayah, ibu dan anak-anak kalau sudah punya anak yang menepati suatu tempat tinggal tertentu, sepanjang pengganti yang mempunyai anak dan tempat tinggal sendiri.

Selanjutnya keluarga yang dikemukakan oleh Ir. M. Munandar Soelaiman tidak jauh berbeda dengan apa yang dikemukakan oleh ahli yag lain yaitu " keluarga adalah suatu satuan terkecil yang dimiliki manusia sebagai mahluk sosial, ditandai adanya kerjasama ekonomi”.

Kemudian penulis mengutif definisi keluarga yang dikemukakan oleh Hairuddin menyatakan sebagai berikut :

Keluarga adalah sebagai suatu kelompok orang di satukan oleh ikatan perkawinan darah atau adopsi merupakan susunan rumah tangga sendiri berintraksi dan berkomunikasi satu sama lain yang menimbulkan peranan sosial bagi suami / istri, putra / putri saudara laki-laki dan perempuan, dan merupakan pemeliharaan kebudayaan bersama.

Dalam undang-undang nomor 10 tahun 1992 keluarga adalah: Unit terkecil dalam masyarakat yang terdiri dari suami/istri atau 
suami/istri dan anak-anaknya, atau ayah dan anak-anaknya, atau ibu dan anak-anakya.

Dari urian tersebut diatas, akhirnya penulis menyimpulkan keluarga adalah merupakan salah satu landasan teori yang penulis anggap penting yang mana keluarga merupakan kelompok primer yang terpenting dalam masyarakat, keluarga adalah unit terkecil dari masyarakat yang terdiri dari orang tua dan anak-anaknya dalam menjalankan suatu ekonomi keluarga.

\section{PEMBAHASAN}

Hasil penelitian dilapangan melalui observasi, penyebaran angket dan dokumentasi didapat hasil sebagai berikut:

\section{Analisis Keharmonisan keluarga}

Tabel 1

Tanggapan responden tentang Kehidupan beragama dalam keluarga

\begin{tabular}{|c|c|c|c|c|c|}
\hline No & $\begin{array}{l}\text { Alternative } \\
\text { jawaban }\end{array}$ & $\begin{array}{c}\text { Bob } \\
\text { ot }\end{array}$ & Frek & $\begin{array}{l}\text { Sk } \\
\text { or }\end{array}$ & $\begin{array}{c}\text { Perse } \\
n\end{array}$ \\
\hline \multirow[t]{5}{*}{ Item 1} & a. $\begin{array}{l}\text { Sangat } \\
\text { taat }\end{array}$ & 5 & 15 & 100 & 50 \\
\hline & b. Taat & 4 & 8 & 32 & 26,67 \\
\hline & $\begin{array}{l}\text { C. Cukup } \\
\text { taat }\end{array}$ & 3 & 3 & 9 & 10 \\
\hline & $\begin{array}{l}\text { Kurang } \\
\text { taat }\end{array}$ & 2 & 2 & 4 & 6,67 \\
\hline & $\begin{array}{ll}\text { e. Sangat } \\
\text { tidak } \\
\text { taat }\end{array}$ & 1 & 2 & 2 & 6,67 \\
\hline & Total & & 30 & 147 & 100 \\
\hline
\end{tabular}

Sumber Data primer diolah 2016

Data tabel tersebut, dapat diketahui bahwa 15 orang atau $50 \%$ responden yang memberikan jawaban sangat taat, 8 orang atau $26,67 \%$ tata, 3 orang atau $10 \%$ cukup taat, 2 orang atau $6,67 \%$ kurang taat, 2 orang atau $6,67 \%$ sangat tidak taat.

\section{Tabel 2}

Tanggapan responden tentang orang tua mempunyai waktu bersama keluarga

\begin{tabular}{|c|c|c|c|c|c|}
\hline No & $\begin{array}{l}\text { Alternative } \\
\text { jawaban }\end{array}$ & $\begin{array}{c}\text { Bobo } \\
\mathrm{t}\end{array}$ & Frek & Skor & Persen \\
\hline $\begin{array}{c}\text { Item } \\
2\end{array}$ & $\begin{array}{l}\text { 1. } \\
\text { Sangat } \\
\text { ada } \\
\text { waktu }\end{array}$ & 5 & 6 & 30 & 20 \\
& $\begin{array}{l}\text { 2. } \\
\text { Selalu } \\
\text { ada } \\
\text { waktu }\end{array}$ & 4 & 13 & 52 & 43,33 \\
3. $\begin{array}{l}\text { Cukup } \\
\text { ada } \\
\text { waktu }\end{array}$ & 3 & 5 & 15 & 16,67 \\
\hline
\end{tabular}

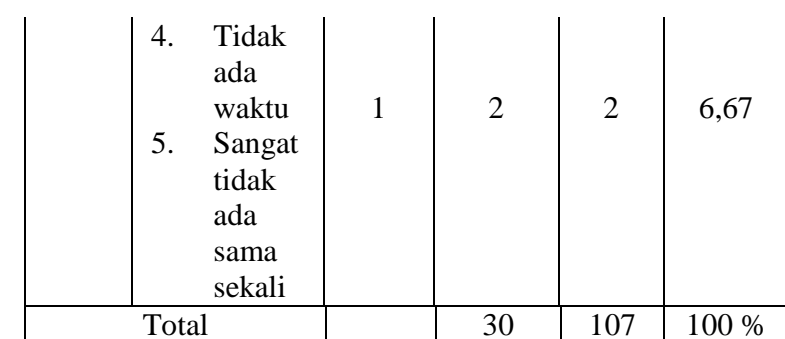

Sumber Data primer diolah 2016

Berdasarkan tabel diatas dapat diketahui bahwa responden yang memberikan jawaban sangat ada waktu sebanyak 6 orang atau $20 \%$, reponden yang menjawab selalu ada waktu sebanyak 13 orang atau 43,33\%, cukup ada waktu 5 orang atau $16,67 \%$, tidak ada waktu 4 orang atau $13,33 \%$ dan sangat tidak waktu 2 atau $6,67 \%$. Hal ini menggambarkan bahwa ada waktu bagi orang tua sangat membantu terjadinya kenakalan pada remaja.

Tabel 3

Tanggapan responden tentang Komunikasi yang baik antara anggota kleuarga

\begin{tabular}{|c|c|c|c|c|c|}
\hline No & Alternative & Bobo & Frek & Skor & Persen \\
\hline $\begin{array}{c}\text { Item } \\
3\end{array}$ & $\begin{array}{ll}\text { a. } & \begin{array}{l}\text { Sangat } \\
\text { baik }\end{array} \\
\text { b. } & \text { Baik } \\
\text { c. } & \text { Cukup } \\
& \text { baik } \\
\text { d. } & \text { Tidak } \\
& \text { baik } \\
\text { e. } & \text { Sangat } \\
& \text { tidak } \\
& \text { baik }\end{array}$ & $\begin{array}{l}5 \\
4 \\
3 \\
2 \\
1\end{array}$ & $\begin{array}{c}10 \\
20 \\
-\end{array}$ & $\begin{array}{l}50 \\
80 \\
-\end{array}$ & $\begin{array}{c}33,33 \% \\
66,67 \% \\
-\end{array}$ \\
\hline \multicolumn{2}{|r|}{ Total } & & 30 & 130 & $100 \%$ \\
\hline
\end{tabular}

Sumber Data primer diolah 2016

Data tabel diatas diketahui bahwa responden yang menjawab sangat baik sebanyak 10 orang atau 33,33\%, responden yang menjawab baik sebanyak 20orang atau $66,67 \%$. Hal ini menunjukkan bahwa adanya komunikasi yang baik antara orang tua dan anak merupakan salah satu factor yang membantu untuk terjadinya kenakalan pada anak-anak remaja. 
Tabel 4

Tanggapan responden tentang Saling menghargai antar sesama anggota keluarga

\begin{tabular}{|c|ll|c|c|c|c|}
\hline No & Alternative jawaban & Bobot & Frek & Skor & Persen \\
\hline Item & a. & Sangat & 5 & 10 & 50 & 33,33 \\
& & $\begin{array}{l}\text { menghargai } \\
\text { b. }\end{array}$ & 4 & 13 & 52 & 43,33 \\
& c. & $\begin{array}{l}\text { Cukup } \\
\text { menghargai }\end{array}$ & 3 & 5 & 5 & 16,67 \\
& d. & $\begin{array}{l}\text { Kurang } \\
\text { menghargai } \\
\text { Tidak sama } \\
\text { sekali }\end{array}$ & 2 & 2 & 4 & 6,67 \\
& Total & 0 & 0 & 0 \\
\hline
\end{tabular}

Sumber data primer diolah 2016

Berdasarkan tabel diatas dapat diketahui bahwa responden yang memberikan jawaban sangat mengharagi sebanyak 10 orang atau $33,33 \%$, reponden yang menjawab mengahargai sebanyak 13 orang atau 43,33\%, sedangkan responden yang menjawab cukup mengahrgai 5 atau $16,67 \%$, kurang menghargai 4 responden atau $6,67 \%$.Hal ini menggambarkan bahwa saling menghargai antar sesame anggota keluarga adalah hal yang dapat mencegah terjadinya kenakalan pada anak remaja.

\section{Tabel 5}

Tanggapan responden tentang Hubungan yang erat antar anggota keluarga

\begin{tabular}{|c|c|c|c|c|c|}
\hline No & $\begin{array}{l}\text { Alternative } \\
\text { jawaban }\end{array}$ & Bobot & Frek & Skor & Persen \\
\hline $\begin{array}{c}\text { Item } \\
5\end{array}$ & $\begin{array}{l}\text { a. Sangat } \\
\text { erat } \\
\text { b. Erat } \\
\text { c. Cukup } \\
\text { erat } \\
\text { d. Kurang } \\
\text { erat } \\
\text { e. Tidak } \\
\text { erat }\end{array}$ & $\begin{array}{l}4 \\
3 \\
2 \\
2 \\
2\end{array}$ & $\begin{array}{c}13 \\
5 \\
2 \\
\\
0\end{array}$ & $\begin{array}{l}50 \\
52 \\
5 \\
\\
4 \\
0\end{array}$ & $\begin{array}{c}33,33 \\
43,33 \\
16,67 \\
6,67 \\
0\end{array}$ \\
\hline & Total & & 30 & 121 & 100 \\
\hline
\end{tabular}

Sumber data primer diolah 2016

Berdasarkan tabel diatas dapat diketahui bahwa responden yang memberikan sangat erat sebanyak 10 orang atau $33,33 \%$, reponden yang menjawab erat sebanyak 13 orang atau $43,33 \%$, cukup erat 5 responden atau 16,67\% dan yang menyatakan kurang erat 2 orang atau $6,67 \%$. Dengan demikian bahwa hubungan yang erat antara sesame anggota keluarga dapat mencegah anak-anak remaja untuk melakukan kenakalan pada dirinya.

\section{Analisis Kenakalan Remaja}

Tabel 6

Tanggapan responden tentang Kenakalan yang menyakiti diri sendiri

\begin{tabular}{|c|ll|c|c|c|c|}
\hline No & Alternative & Bobot & Frek & Skor & Persen \\
\hline Item 1 & a. & Ya sering & 5 & 0 & 0 & 0 \\
& & terjadi & 4 & 0 & 0 & 0 \\
& b. Ada & 3 & 3 & 9 & 10 \\
& c. $\quad$ Cukup ada & 2 & 20 & 40 & 66,66 \\
& d. Kurang ada & 1 & 7 & 7 & 23,34 \\
& e. Tidak ada & & & & \\
\hline \multicolumn{2}{|l|}{ Total } & & 30 & 56 & 100 \\
\hline
\end{tabular}

Sumber data primer diolah 2016

Dari data tabel di atas menunjukkan bahwa responden yang memberikan jawaban dengan kategori cukup ada sebanyak 3 orang atau 10 $\%$, responden yang memberikan jawaban dengan kategori tidak ada sebanyak 7 orang atau $23,33 \%$.

Tabel 7

Tanggapan responden tentang Kenakalan fisik pada orang lain

\begin{tabular}{|c|c|c|c|c|c|}
\hline No & Alternative & Bobot & Frek & Skor & Persen \\
\hline Item & a. Ya sering terjadi & 5 & 0 & 0 & 0 \\
\hline \multirow[t]{4}{*}{2} & b. Ada & 4 & 0 & 0 & 0 \\
\hline & c. Cukup ada & 3 & 3 & 9 & 10 \\
\hline & d. Kurang ada & 2 & 20 & 40 & 66,66 \\
\hline & e. Tidak ada & 1 & 7 & 7 & 23,34 \\
\hline \multicolumn{2}{|r|}{ Total } & & 30 & 56 & 100 \\
\hline
\end{tabular}

Sumber data primer diolah 2016

Dari data tabel di atas menunjukkan bahwa responden yang memberikan jawaban dengan kategori cukup ada sebanyak 3 orang atau 10 $\%$, responden yang memberikan jawaban dengan kategori tidak ada sebanyak 7 orang atau $23,33 \%$.

Tabel 8

Kenakalan yang menimbulkan korban materi

\begin{tabular}{|c|c|c|c|c|c|}
\hline No & Alternative & Bobot & Frek & Skor & Persen \\
\hline Item & a. Sangat ada & 5 & 0 & 0 & 0 \\
\hline \multirow[t]{4}{*}{3} & b. Ada & 4 & 4 & 16 & 13,33 \\
\hline & c. Cukup ada & 3 & 7 & 21 & 23,33 \\
\hline & d. Tidak ada & 2 & 10 & 20 & 33,34 \\
\hline & $\begin{array}{ll}\text { e. } & \begin{array}{l}\text { Sangat } \\
\text { tidak ada }\end{array} \\
\end{array}$ & 1 & 9 & 9 & 30 \\
\hline \multicolumn{2}{|r|}{ Total } & & 30 & 66 & 100 \\
\hline
\end{tabular}

Sumber data primer diolah 2016

Dari data tabel di atas menunjukkan bahwa responden yang memberikan jawaban dengan kategori ada 4 responden atau (13,33\%), cukup ada 7 responden $(23,33 \%)$, tidak ada 10 responden atau $(33,34)$, sangat tidak ada 9 responden atau $(30 \%)$. Hal ini berarti bahwa kenakalan yang dilakukan oleh remaja yang menimbulkan korban materi seperti perusakan, pencurian, pencopetan dan pemerasan tidak ada yang melakukan hal tersbut. Dengan 
demikian karena keberfungsian sosial keluarga berjalan dengan baik maka hal-hal tersebut diatas tidak terjadi.

Tabel 9

Tanggapan responden tentang Kenakalan sosial yang tidak menimbulkan korban fisik

\begin{tabular}{|c|c|c|c|c|}
\hline No & Alternative & Bobot & Frek & Skor \\
\hline Item & a. $\quad$ Ya ada & 5 & 0 & 0 \\
\hline 4 & b. Ada & 4 & 0 & 0 \\
\hline & c. Cukup ada & 3 & 4 & 60 \\
\hline & d. Tidak ada & 2 & 6 & 10 \\
\hline & $\begin{array}{l}\text { e. Tidak ada } \\
\text { sama sekali }\end{array}$ & 1 & 20 & 5 \\
\hline \multicolumn{2}{|r|}{ Jumlah } & & 30 & 75 \\
\hline
\end{tabular}

Sumber data primer diolah 2016

Dari data tabel di atas menunjukkan bahwa responden yang memberikan jawaban dengan cukup ada sebanyak 4 orang atau 13,34\%, responden yang memberikan jawaban dengan kategori cukup ada sebanyak 6 orang atau 20 $\%$ sedangkan responden yang memberikan jawaban dengan kategori tidak ada sama sekali tersebut sebanyak 20 orang atau 66,67\%. Berdasarkan jawaban yang diberikan bahwa kenakalan social yang tidak menimbulkan korban fisik seperti pelacuran, penyalahgunaan obat, hubungan seks bebas sebagian responden tidak ada sama sekali.

\section{Tabel 10}

Kenakalan yang melawan status

\begin{tabular}{|c|c|c|c|c|c|}
\hline No & Alternative & Bobot & Frek & skor & Persen \\
\hline Item & a. $\quad$ Sangat ada & 3 & 0 & 0 & 0 \\
\hline 5 & b. Ada & 4 & 0 & 0 & 0 \\
\hline & c. Cukup ada & 3 & 0 & 0 & 0 \\
\hline & d. Tidak ada & 2 & 0 & 0 & 0 \\
\hline & $\begin{array}{l}\text { e. Tidak sama } \\
\text { sekali }\end{array}$ & 1 & 30 & 30 & $100 \%$ \\
\hline \multicolumn{2}{|r|}{ Total } & & 30 & 30 & $100 \%$ \\
\hline
\end{tabular}

Sumber data primer diolah 2016

Dati data tabel diatas menunjukkan bahwa responden yang memberikan jawaban dengan kategori mengalami melawan satus semua responden sebanyak 30 orang atau 100 persen semua responden mengatakan tidak melakukan melawan status sosial seperti mengingkari status anak sebagai pelajar dengan cara membolos, minggat dari rumah, membantah perintah.

Pengujian hipotesa menggunakan uji statistik product moment corelation adalah :

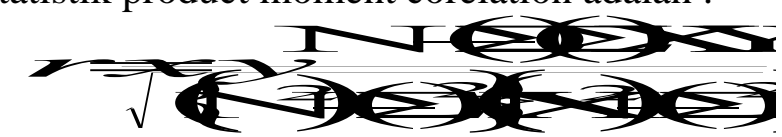

$$
r x y=\frac{30 \times 12.558-(590)(621)}{\left.\sqrt{\left\{(30 \times 12.348)-(590)^{2}\right\}(30 \times 13.040)-(621)^{2}}\right\}}
$$

$$
\begin{aligned}
& r x y=\frac{376.740-366.390}{\sqrt{(370.440-348.100)(391.200-385.641)}} \\
& r x y=\frac{10.350}{\sqrt{(27.340)(5.559)}}
\end{aligned}
$$

$\underset{0}{\text { Persen }}=\frac{10.350}{\sqrt{151.938 .060}}=\frac{10.350}{12.328}=0,839$

13,3Berdasarkan perhitungan hasil pengujian hipotesa tersebut maka didapatkan nilai 6.66riabel X dan $\mathrm{Y}$ adalah 0,899 sedangkan nibai tabel kritik untuk sampel $n=30$ adalah sebesar 0,361 dengan derajat kebenaran $5 \%$ artinya hipotesa yang diajukan diterima (terdapat hubungan yang kuat) antara keharmonisan keluarga dengan kenakalan remaja ketentuan semula jika t hitung $>$ dari tabel yang ditentukan.

Dengan demikian penelitian yang dilakukan oleh peneliti mengenai peran keharmonisan keluarga terhadap kecenderungan kenakalan remaja di Desa Tanjung Raman Kecamatan Pendopo Kabupaten Empat Lawang berhasil dengan sangat baik.

\section{KESIMPULAN}

1. Berdasarkan analisis di atas, ditemukan bahwa remaja yang didalam kehidupan keluarganya kurang harmonis dengan baik seperti adanya komunikasi antara orang tua dan anak, kehidupan beragama yang baik, hubungan yang erat antar anggota keluarga, dan adanya waktu yang luang bagi orang tua untuk berkumpul dengan anggota keluarga khususnya anak-anak mereka, maka kemungkinannya lebih kecil anak-anak untuk melakukan kenakalan atau perilaku menyimpang. Demikian juga dari keluarga yang tidak harmonis maka kemungkinan besar anaknya akan melakukan kenakalan pada tingkat yang lebih berat. Sebaliknya bagi keluarga yang keharmonisannya tinggi maka kemungkinan anak-anaknya melakukan kenakalan sangat kecil, apalagi kenakalan khusus.

2. Dari analisis statistik (kuantitatif) dapat ditarik kesimpulan umum bahwa ada 
E. ISSN : 2746-1629

hubungan positif antara keharmonisan keluarga dengan kenakalan remaja, artinya bahwa semakin harmonis sebuah keluarga akan semakin rendah kenakalan yang dilakukan oleh remaja. Sebaliknya semakin tidak harmonisnya suatu keluarga maka semakin tinggi tingkat kenakalan remajanya (kenakalan remaja yang dilakukan oleh remaja.

\section{DAFTAR PUSTAKA}

Gunarsa, Singgih D. 2008. Psikologi Anak: Psikologi Perkembangan Anak dan Remaja. Jakarta: PT BPK Gunung Mulia

Hawari D, 2000. Manajemen Cemas dan Depresi. Jakarta : Balai Penerbit Fakultas Kedokteran Universitas Indonesia.

Kartono, kartini. 2003, Psikologi Sosial, Kenakalan Remaja, Rajawali, Jakarta

M.Munandar Soelaiman,1984, Wanita Kesehatan Dan Keluarga Berencana, Jakarta : Sinar Harapan,

Mussen, P. H., dkk. 2000. Perkembangan dan Kepribadian Anak. Jakarta: ARCAN

Sarlito Wirawan Sarwono. 2003. Psikologi Remaja. Jakarta: PT. Raja Grafindo Persada.

Sekamto, Soerjono. 1998, Keluarga dan Masyarakat, Jakarta : Gramedia 